\title{
Phenolic Metabolites of Dalea ornata Affect Both Survival and Motility of the Human Pathogenic Hookworm Ancylostoma ceylanicum
}

\author{
Kaitlin Deardorff ${ }^{\dagger}$, William Ray ${ }^{\ddagger}$, Eric Winterstein ${ }^{\ddagger}$, MacKenzie Brown ${ }^{\ddagger}$, Jocelyn \\ McCornack $^{\dagger}$, Brianda Cardenas-Garcia ${ }^{\dagger}$, Kiah Jones $^{\dagger}$, Sarah McNutt ${ }^{\dagger}$, Shannon Fulkerson ${ }^{\dagger}$, \\ Daneel Ferreira ${ }^{\S}$, Charlotte Gény ${ }^{\perp}$, Xiaoyan Chen $^{\perp}$, Gil Belofsky ${ }^{\ddagger},{ }^{*}$, and Blaise Dondji ${ }^{,}{ }^{*}$ \\ †Laboratory of Cellular Immunology and Parasitology, Department of Biological Sciences, Central \\ Washington University, Ellensburg, Washington 98926, United States \\ ¥Department of Chemistry, Central Washington University, Ellensburg, Washington 98926, United \\ States \\ $\S$ Department of BioMolecular Sciences, Division of Pharmacognosy, and the Research Institute of \\ Pharmaceutical Sciences, School of Pharmacy, The University of Mississippi, University, \\ Mississippi 38677, United States \\ ${ }^{\perp}$ Department of Drug Discovery and Biomedical Sciences, The Medical University of South \\ Carolina, Charleston, South Carolina 29425, United States
}

\begin{abstract}
Hookworms are ubiquitous human parasites, infecting nearly one billion people worldwide, and are the leading cause of anemia and malnutrition in resource-limited countries. Current drug treatments rely on the benzimidazole derivatives albendazole and mebendazole, but there is emerging resistance to these drugs. As part of a larger screening effort, using a hamster-based ex vivo assay, anthelmintic activity toward Ancylostoma ceylanicum was observed in the crude extract of aerial parts of Dalea ornata. These studies have led to the isolation and characterization of phenolic metabolites 1-10. The structures were determined by 1D and 2D NMR spectroscopy, and the absolute configuration of $\mathbf{1}$ was assigned using electronic circular dichroism data. The new compound, (2S)-8-(3-methylbut-2-en-1-yl)-6,7,4'-trihydroxyflavanone (1), was weakly active at $7.3 \mu \mathrm{M}$, with $17 \%$ reduction in survival of the hookworms after 5 days. The rotenoids deguelin (9) and tephrosin (10), predictably perhaps, were the most active, with complete worm mortality
\end{abstract}

*Corresponding Authors. Tel: 509-963-2882. Fax: 509-963-1050. BelofskyG@cwu.edu. Tel: 509-963-2715. Fax: 509-963-2370. DondjiB@cwu.edu.

DEDICATION

This article is dedicated to the memory of our coauthor Mr. Eric Winterstein, 26, a talented young scientist who passed away in a tragic accident in June 2016.

\section{ASSOCIATED CONTENT}

Supporting Information

The Supporting Information is available free of charge on the ACS Publications website at DOI: 10.1021/acs.jnatprod.6b00444.

ECD spectrum of compound $\mathbf{1} ;{ }^{1} \mathrm{H},{ }^{13} \mathrm{C}$, HSQC, HMBC, and COSY spectra of compounds $\mathbf{1 - 3}, \mathbf{5}, \mathbf{6}$, and $\mathbf{9}$; and ${ }^{1} \mathrm{H}$ and ${ }^{13} \mathrm{C}$ NMR spectra of compounds $4,7,8$, and $10(\mathrm{PDF})$

The authors declare no competing financial interest. 
observed by day 4 (or earlier) at 6.3 and $6.0 \mu \mathrm{M}$, respectively. The effects of 1-10 on hookworm motility and on toxicity to hamster splenocytes were also explored as important measures of treatment potential.

\section{Graphical abstract}

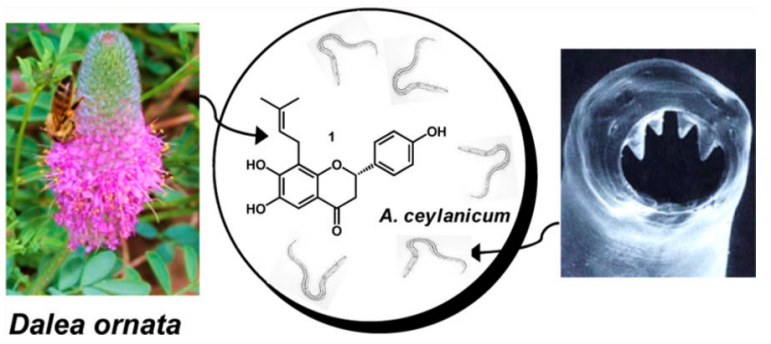

Hookworms are intestinal parasites that infect close to a billion people worldwide, largely in rural areas of sub-Saharan Africa, Central and South America, Southeast Asia, and mainland China. ${ }^{1,2}$ The majority of human hookworm infections are caused by Necator americanus and Ancylostoma duodenale, with foci of Ancylostoma ceylanicum in Asia. ${ }^{3-7}$ Of these three species, only $A$. ceylanicum infects both humans and animals and consequently has been used for laboratory studies in animal models. ${ }^{6,8-10}$ Hookworm eggs are present in the feces of infected individuals and thrive in warm, moist soil, where they undergo successive molts to the infective stage three larvae (L3). One route of infection therefore occurs when these L3 larvae come into contact with and penetrate the skin of a susceptible host and gain access to the cardiovascular system. Ultimately, the larvae migrate to the lungs and airways, reaching the trachea, where they are swallowed and eventually enter the small intestine. The parasites undergo successive molts to the adult stage in the host small intestine, where they attach to the mucosa. Here the worms feed on tissues, lacerating capillaries and sucking blood in a process that is maintained by parasite-secreted inhibitors of coagulation and platelet function. ${ }^{8,11-13}$ This blood-feeding stage leads to blood loss by the host followed by anemia. The worms are also able to migrate and reattach at new sites. Infection with Ancylostoma spp. can also occur through the oral route.

Hookworm infection is listed among the neglected tropical diseases. These conditions affect populations living in poverty and attract less scientific interest, particularly in the pharmaceutical industry, where it is believed that treatment of such diseases lacks sufficient financial return on investment. Consequently, studies aimed at discovering new treatments are lacking. Other obstacles might be related to the difficulty of working with the organisms in the laboratory, particularly in keeping the worms alive outside a living host.

In endemic areas, hookworm infection is a leading cause of anemia and malabsorption/ malnutrition, related to protein loss due to intestinal bleeding. ${ }^{14,15}$ These nutritional losses create particular risks for pregnant and nursing women, with children suffering low birth weight and cognitive defects. Also, human and animal studies suggest that hookworm infection is associated with suppression of the host immune response, including reduced lymphocyte proliferation and depletion of the CD4+ T cell populations. ${ }^{9}{ }^{910}$ This subset of immune cells is the center of the immune response to infections and vaccines. Thus, reports 
demonstrating that hookworm affects host immune responses to vaccines and co-infecting pathogens that cause AIDS, malaria, leishmaniasis, and tuberculosis are not surprising. ${ }^{16-20}$ The benzimidazole-based anthelmintic agents mebendazole and albendazole are utilized widely as part of targeted deworming campaigns recommended by the World Bank and World Health Organization. ${ }^{21,22}$ However, a single dose regimen of these benzimidazoles has limited efficacy against hookworm, and reinfection often occurs within months. In order to make a meaningful impact, anthelmintic chemotherapy might need to be administered several times per year to avoid selective pressure on the organisms that may explain emerging resistance. ${ }^{23}$ Recent field studies in Ghana, for example, revealed greatly reduced effectiveness of albendazole, with treatment failure rates of $39-56 \% .^{24,25}$ The widespread prevalence of hookworm disease, associated social and economic impact, and increasingly limited options for treatment suggest an urgent need for complementary and alternative treatments. Non-benzimidazole agents, having other modes of action, may be preferable in view of the observed emerging resistance.

Remarkably few prior drug discovery efforts for hookworm disease can be found. A recent SciFinder (Chemical Abstracts Service, Columbus, $\mathrm{OH}$ ) search, for example, revealed two prior reports in which plant extracts or compounds were tested against $A$. ceylanicum, but none of the isolates exhibited significant anthelmintic activity. ${ }^{26,27}$ A panel of azole-inspired synthetic compounds, consisting of nitrogen- and oxygen-containing heterocycles (e.g., furoxan analogues), was tested against various $A$. ceylanicum isolates in a more recent study that revealed differences in susceptibility of laboratory versus field isolates of Ancylostoma spp. $^{28}$

In the present study, an ex vivo bioassay was employed to assess the effects of plant isolates on the adult hookworm A. ceylanicum. Screening of representatives of three plant families (Fabaceae, Rosaceae, and Saxifragaceae) revealed that the crude methanol extract of the aerial portions of Dalea ornata was the most active surveyed, causing a $63 \%$ reduction in survival after 2 days at $100 \mu \mathrm{g} / \mathrm{mL}$. Methanol extracts of the roots were essentially inactive. Dalea ornata (Hook.) Eaton \& J. Wright (Fabaceae), Blue Mountain prairie clover, is native to the shrub-steppe habitats of the southern Columbia Plateau, the Blue Mountains, and the northern Great Basin in the United States. It is similar in morphology to Dalea searlsiae (A. Gray) Barneby, and these plants share a geographic distribution, although $D$. searlsiae can be found further south in the Great Basin and into Arizona. The two plants exhibit minor taxonomic differences. $D$. ornata tends to have more crowded, compact flower spikes, for example, and leaflets up to $20 \mathrm{~mm}$ that are widely ovate to elliptic compared to those of $D$. searlsiae, which are up to $16 \mathrm{~mm}$ and obovate to oblong. ${ }^{29,30}$ It may not be surprising, therefore, that constituents found recently in $D$. searlsiae ${ }^{31}$ were also isolated from extracts of $D$. ornata in the present study. Herein, the structures and associated biological activities of one new and nine known flavonoids, including two rotenoids and one pterocarpan, are reported. Their structures were defined by NMR and HRMS techniques, and the absolute configuration of compound $\mathbf{1}$ was assigned using electronic circular dichroism (ECD) data. Such chiroptical application highlights the growing utility of this technique ${ }^{32}$ toward the reliable definition of the absolute configurations of this class of plant secondary metabolites. 

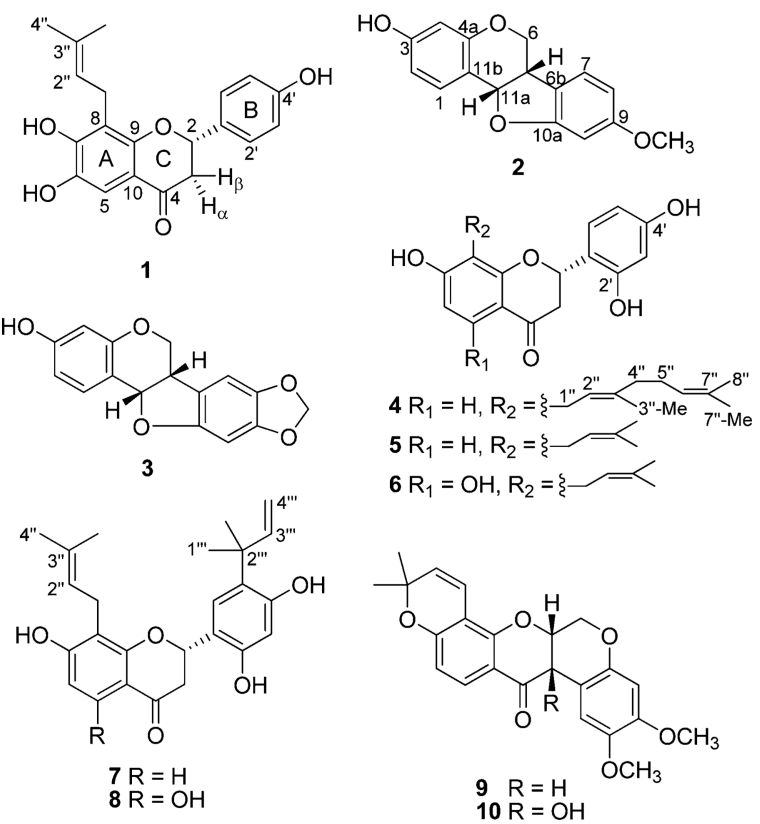

\section{RESULTS AND DISCUSSION}

The active crude extract of the aerial portions of $D$. ornata was fractionated by silica gel vacuum-liquid chromatography (VLC). Bioassay of the resulting fractions revealed that the most potent ex vivo inhibition of survival was concentrated in fractions of medium polarity that eluted with EtOAc (40-80\%) in hexanes. The anthelmintic activity of this pooled, enriched material exhibited the expected dose dependence and an approximate 2-fold increase in potency, with a day 2 survival of $43 \%$ at $50 \mu \mathrm{g} / \mathrm{mL}$, compared to $37 \%$ survival at $100 \mu \mathrm{g} / \mathrm{mL}$ for the crude extract (Figure 1).

The HRESIMS, ${ }^{13} \mathrm{C}$ NMR (Table 1), and DEPT data for compound $\mathbf{1}$ indicated a molecular formula of $\mathrm{C}_{20} \mathrm{H}_{20} \mathrm{O}_{5}$. A pattern characteristic of a flavanone core structure was indicated by HSQC correlations between the oxymethine at $\delta_{\mathrm{H}} 5.38(\mathrm{dd}, \mathrm{H}-2)$ and the methylene proton resonances at $\delta_{\mathrm{H}} 2.96(\mathrm{dd}, \mathrm{H}-3 \mathrm{a})$ and $2.72(\mathrm{dd}, \mathrm{H}-3 \beta)$ and their respective carbons at $\delta_{\mathrm{C}}$ 80.5 and 44.9. Comparison of the observed coupling constants between $\mathrm{H}-2$ and $\mathrm{H}_{2}-3$ (Table 1) with published values ${ }^{31}$ also supported the relative configuration shown. The ${ }^{13} \mathrm{C}$ NMR and DEPT data indicated the presence of nine nonprotonated carbons, including a keto carbonyl at $\delta_{\mathrm{C}} 191.1$ and four oxygenated $\mathrm{sp}^{2}$ carbons between $\delta_{\mathrm{C}} 140$ and 159 . Three of these sites of oxygenation were due to hydroxy groups, the associated protons of which were observed in the ${ }^{1} \mathrm{H}$ NMR spectrum, with C-9 accounting for the fourth site. A pair of coupled $(8.5 \mathrm{~Hz})$ doublets at $\delta_{\mathrm{H}} 7.40(\mathrm{~d}, 2 \mathrm{H})$ and $6.89(\mathrm{~d}, 2 \mathrm{H})$ indicated a disubstituted Bring. The absence of a hydrogen-bonded (typically $\delta_{\mathrm{H}} 11-13$ ) hydroxy proton suggested that C-5 is protonated $\left(\delta_{\mathrm{H}} 7.18, \mathrm{~s}\right)$. An HMBC correlation between H-5 and C-4 $\left(\delta_{\mathrm{C}} 191.1\right)$ provided support for this, accounting for all observed aromatic protons and requiring that 1 possesses a trisubstituted A-ring. The molecular formula supported the presence of a prenyl group as the fourth aromatic substituent. Its placement at C-8 was confirmed through HMBC 
correlations from $\mathrm{H}_{2}-1^{\prime \prime}\left(\delta_{\mathrm{H}} 3.35, \mathrm{~d}\right)$ to $\mathrm{C}-7, \mathrm{C}-8$, and $\mathrm{C}-9$ and from $\mathrm{H}-2^{\prime \prime}\left(\delta_{\mathrm{H}} 5.24, \mathrm{~m}\right)$ to $\mathrm{C}-8$. The dimethylallyl rather than the isopentenyl constitution of this group was verified with $\mathrm{HMBC}$ correlations from the Me- $3^{\prime \prime}$ and $\mathrm{H}_{3}-4$ " protons at $\delta_{\mathrm{H}} 1.64$ and 1.62, respectively, to both $\mathrm{C}-2^{\prime \prime}$ and $\mathrm{C}-3^{\prime \prime}$. With the above relationships established, the three hydroxy groups were necessarily located at C-6, C-7, and C-4'. The overall structural connectivity was established by HSQC, HMBC, and COSY spectroscopic data (Figures S2S6, Supporting Information) and by comparison with known compounds. ${ }^{28,30}$ ECD data were used to define the absolute configuration at $\mathrm{C}-2$ in compound $\mathbf{1}$. The ECD spectrum (Figure S1, Supporting Information) showed sequential positive and negative Cotton effects near 350 and $310 \mathrm{~nm}$ for the $\mathrm{n} \rightarrow \pi^{*}$ and $\pi \rightarrow \pi^{*}$ electronic transitions, respectively. Such a pattern is reminiscent of flavanones exhibiting $P$-helicity of the conformationally flexible heterocyclic ring with a $\mathrm{C}-2$ equatorial aryl group and, hence, $(2 S)$ absolute configuration. ${ }^{32}$ This assignment is supported by the observed levorotatory properties of compound $\mathbf{1}$. Thus, the structure of 1 was defined as the new (2S)-8-(3-methylbut-2-en-1-yl)-6,7,4' trihydroxyflavanone. Compound $\mathbf{1}$ is the 5-deoxy analogue of the known compound nirurinetin, ${ }^{33}$ for which the specific rotation and, thus, absolute configuration were not assigned.

The ${ }^{1} \mathrm{H}$ NMR spectrum of $\mathbf{2}$ showed six aromatic protons comprising two sets of threeproton $\mathrm{ABC}$ spin systems. Two methine $\left(\delta_{\mathrm{H}} 5.51\right.$ and 3.60) and oxymethylene $\left(\delta_{\mathrm{H}} 4.26\right.$ and 3.58) proton signals of the C-ring spin system correlated to carbons at $\delta_{C} 79.5,40.5$, and 67.2, respectively, in the HSQC spectrum, a pattern characteristic of a pterocarpan core structure. This arrangement was supported by COSY, HSQC, and HMBC spectroscopic data, which, for example, confirmed the location of the methoxy group $\left(\delta_{H} 3.75\right)$ at C-9. An HMBC correlation from the coupled $(J=8.4 \mathrm{~Hz}) \mathrm{H}-1$ to C-11a permitted the establishment of the substitution pattern of the A-ring as shown. The structure of $\mathbf{2}$ was further supported by HRESIMS data that indicated a molecular formula of $\mathrm{C}_{16} \mathrm{H}_{14} \mathrm{O}_{4}$ and comparison of $1 \mathrm{D}$ NMR spectroscopic data to literature values ${ }^{34}$ and was revealed by its specific rotation to be (+)-medicarpin.

The HRESIMS, ${ }^{13} \mathrm{C}$ NMR, and DEPT data for compound $\mathbf{3}$ indicated a molecular formula of $\mathrm{C}_{16} \mathrm{H}_{12} \mathrm{O}_{5}$. Key HMBC correlations revealed the connectivity between C-6, C-6a, and $\mathrm{C}-11 \mathrm{a}$ and their attached protons, and COSY correlations among these supported the presence of a pterocarpan system. A distinctive carbon resonance at $\delta_{C} 102.2$, along with HSQC data, indicated the presence of a methylenedioxy group. The placement of this group at C-8/C-9 and the overall structure of the molecule were established by HSQC and HMBC correlations. The 1D NMR spectroscopic data were consistent with reported literature values for maackiain; 35 the large positive specific rotation, $[a]^{20} D+102$, confirmed it to be the dextrorotatory enantiomer. The (+)-isomer is rarely observed, but was reported ${ }^{35}$ previously as a metabolite of Dalea purpurea (syn: Petalostemon purpureus), perhaps suggesting a conserved biosynthetic pathway for these closely related Dalea spp.

The known compounds (-)-malheuran A (4), (-)-malheuran B (7), the (2S)-flavanone 8, and (-)-tephrosin (10) were identified by ${ }^{1} \mathrm{H}$ and ${ }^{13} \mathrm{C}$ NMR spectroscopic data comparison (Figures S17, S18, S29-S32, S38, and S39, Supporting Information), HRESIMS, and TLC comparison to authentic samples of these compounds, previously isolated from the closest 
"relative" of D. ornata, D. searlsiae. ${ }^{31}$ Specific rotations for these four compounds confirmed the absolute configurations that were previously established via ECD data. ${ }^{31}$ The structures of the known compounds $\mathbf{5 , 6}$, and $\mathbf{9}$ were readily elucidated with $1 \mathrm{D}$ and 2D NMR spectroscopic data (Figures S19-S28, S33-S37, Supporting Information) and by HRESIMS data analysis. Comparison of the 1D NMR data and specific rotations with published values confirmed the structures and absolute configurations of (-)-euchrenone-a7 (5), ${ }^{36,37}(2 S)$-leachianone $\mathrm{G}(\mathbf{6}),{ }^{38-40}$ and (-)-deguelin $(\mathbf{9})^{41}$ as shown.

The results of ex vivo testing of 1-10 are shown in Table 2. A test concentration of 25 $\mu \mathrm{g} / \mathrm{mL}$ was chosen to compare all 10 compounds that were isolated. The new compound 1 was weakly active at $7.3 \mu \mathrm{M}$, causing only $17 \%$ mortality by day 5 of the assay. Considering that motility of the worms will affect their ability to feed on the intestinal wall of the host and cause any clinical symptoms, the effect of compounds on worm motility was recorded. The effect of compound $\mathbf{1}$ on motility was equally weak, and worms incubated with this compound remain active by day 5 postincubation (PI). (-)-Maackian $(3,8.2 \mu \mathrm{M})$ exhibited weak to moderate effects, with $27 \%$ mortality observed on day 5 . An average motility of 2.5 out of 3 for compound $\mathbf{3}$ at the end of the assay, indicating worms that retained $\sim 80 \%$ of their motility, was observed. Toxicity of the compounds to the host was measured by examining their effects on cell proliferation, considering that one of the immediate responses of the immune system in the context of an infection is increased cell division. Cell proliferation was expressed as stimulation index (SI; see Experimental Section). An SI of 1 reflects the absence of compound effect on splenocyte proliferation, while values markedly below 1 or higher than 1 reveal a negative effect. Compounds $\mathbf{1}$ and $\mathbf{3}$ did not affect hamster splenocyte proliferation, as indicated by SI values of 0.8 and 1, respectively. While compounds 1 and 3-7 exhibited only mild anthelmintic activity, their presence in the crude extract and the subsequent enriched VLC fraction (Figure 1) suggests that they may contribute to the overall strong activity observed in these materials. The known rotenoids (-)-deguelin (9) and (-)-tephrosin (10) were the most effective at killing adult $A$. ceylanicum (Table 2), with complete mortality observed by day 4 for the two compounds at 6.3 and $6.0 \mu \mathrm{M}$, respectively. (-)-Tephrosin (10) continued to exhibit strong anthelmintic activity at a lower dose, with complete mortality observed on day 3 of the assay at $10 \mu \mathrm{g} / \mathrm{mL}$ $(2.4 \mu \mathrm{M})$. This is the first report of plant-derived natural products with demonstrated efficacy toward hookworm. Rotenoids, including $\mathbf{9}$ and 10, have long been known for their antiinsectan and piscicidal activities. ${ }^{31,42}$ Their known mechanism of action is to interfere with oxidative phosphorylation, blocking the transfer of electrons to ubiquinone by complexing with NADH:ubiquinone oxidoreductase of the respiratory electron transport chain. ${ }^{43}$ In vitro cell viability studies for $\mathbf{9}$ and $\mathbf{1 0}$ have been done previously on several mammalian cancer cell lines, revealing no cytotoxicity at concentrations up to $30 \mu \mathrm{M} .{ }^{44}$ The known toxicity of rotenoids to live mammals can be high, depending on the formulation and route of exposure. With oral administration, however, toxicity can be quite low. The parent compound rotenone, for example, was reported to have an $\mathrm{LD}_{50}$ value of $132-1500 \mathrm{mg} / \mathrm{kg}$ in rats when orally administered. ${ }^{45}$ In this study, the toxicity of the 10 compounds to hamster splenocytes, measured as effect on cell proliferation, was minimal, as shown by stimulation indices ranging between 0.8 and 1.0. Conversely, the stimulation index in the positive control wells containing concanavallin A (ConA), a known T lymphcocyte mitogen, was 5.8. 
Previous reports have shown stimulation indices of naiie spleen cells to ConA ranging from 6 to $6.8 .9,10$

In this ongoing collaborative project, the additional screening and evaluation of other plant isolates are currently under way, in preparation for in vivo work using oral gavage as the route of administration. Compounds $\mathbf{9}$ and $\mathbf{1 0}$ may prove to be viable candidates for this work. Along with screening results, these will be the subject of a future communication.

\section{EXPERIMENTAL SECTION}

\section{General Experimental Procedures}

Melting points were measured on an SRS MPA160 DigiMelt apparatus. Optical rotations were recorded on a PerkinElmer 341 polarimeter (Na lamp, $589 \mathrm{~nm}$ ); concentrations are reported in $\mathrm{g} / 100 \mathrm{~mL}$. UV spectra were recorded on an HP-Agilent 8453 photodiode array instrument. ECD spectra were obtained on an Aviv Biomedical, Inc. M400 circular dichroism spectrometer using dry $\mathrm{MeOH}$ as the solvent and a $0.1 \mathrm{~cm}$ path length quartz cuvette. IR spectra were recorded on a Nicolet Protégé 460 spectrometer. NMR spectra were obtained on a Bruker Avance $400 \mathrm{MHz}$ system with Topspin 1.3 software. HRESIMS data were recorded on a Waters Q-TOF Premier hybrid mass spectrometer. A Waters Acquity UPLC was used to inject samples in 1:1 $\mathrm{MeCN}-\mathrm{H}_{2} \mathrm{O}$ using flow injection analysis $(100 \mu \mathrm{L} /$ min) with no intervening column. Negative ESIMS was used to generate $[\mathrm{M}-\mathrm{H}]^{-}$ions. Preparative linear gradient chromatography employed a custom twochamber apparatus creating a continuous gradient, with gravity flow ( $20 \mathrm{~mL} / \mathrm{min})$, over $60-100$ mesh silica gel. This was connected to glass columns of varying sizes sealed with PTFE end-fittings. Samples were preadsorbed onto silica gel in solution and evaporated to dryness prior to loading onto the column. Eluting solvent percentages given (see Extraction and Isolation) represent estimates, for the sake of reproducibility, of the solvent compositions entering the column. Collection of 20 fractions $(20 \mathrm{~mL})$ for example, with a linear gradient of EtOAc (0$100 \%$ ) in hexanes, will result in fraction 10 having a composition of $~ 50 \%$ EtOAc. Silica gel step-gradient columns also employed 60-100 mesh silica gel and were run with preadsorbed samples. TLC plates (Sigma-Aldrich; silica gel $60, \mathrm{~F}_{254}$ ) were eluted with mixtures of $\mathrm{MeOH}$ in $\mathrm{CH}_{2} \mathrm{Cl}_{2}$ or of EtOAc in hexanes and visualized with UV $(254 \mathrm{~nm})$ and the spray reagent vanillin- $\mathrm{H}_{2} \mathrm{SO}_{4}(1 \mathrm{~g} / 100 \mathrm{~mL}$ w/v $)$ followed by gentle heating.

\section{Plant Material}

Whole plants of D. ornata were collected by G. Belofsky, M. Aronica, and L. Belofsky on June 27, 2012, at two different roadside sites near Pasco and Richland, WA, GPS coordinates $\mathrm{N} 46^{\circ} 17.620^{\prime}$, W $119^{\circ} 11.629^{\prime}$, alt $551 \mathrm{ft}$ and $\mathrm{N} 46^{\circ} 21.598^{\prime}$, W $119^{\circ} 21.618^{\prime}$, alt $482 \mathrm{ft}$, respectively. A voucher specimen was authenticated by Dr. Tom Cottrell, Department of Biological Sciences, Central Washington University, and has been deposited in the herbarium of the same department, accession no. 2012003GB. Roots and aerial portions were separated, and aerial portions were air-dried for several days and stored $\left(-20^{\circ} \mathrm{C}\right)$ prior to extraction. 


\section{Extraction and Isolation}

Aerial portions of $D$. ornata (leaves, stems, and flowers) from both collection sites were extracted separately with $\mathrm{MeOH}$ in a Waring blender for 2-3 min. The mixtures were each filtered, and the filtrates were evaporated under reduced pressure. These crude extracts were found to be identical by TLC analysis and combined to yield $46 \mathrm{~g}$ of crude extract from a total of $492 \mathrm{~g}$ of plant material extracted in $10 \mathrm{~L}$ of $\mathrm{MeOH}$. The combined crude extract was preadsorbed in $\mathrm{MeOH}$ solution onto $\sim 10 \mathrm{~g}$ of silica gel, the solvent removed under vacuum, and the resulting powder subjected to VLC over a prepacked column bed $(10 \times 6 \mathrm{~cm}$; i.d. $\times$ h) of TLC-grade (230-400 mesh) silica gel. The column was eluted using a stepwise gradient of solvents beginning with hexanes $(2 \mathrm{~L})$ and continuing with mixtures $(1 \mathrm{~L}$ each) of EtOAc in hexanes $(20,40,60,80$, and $100 \%$ EtOAc), followed by mixtures of $\mathrm{MeOH}$ in $\mathrm{CH}_{2} \mathrm{Cl}_{2}(2,5,8,10$, and $30 \% \mathrm{MeOH})$. Material from fractions 3-5 (1.9 g) from this column that exhibited significant activity in the ex vivo assay was further separated by Sephadex LH-20 (Sigma-Aldrich) column chromatography $(2.5 \times 88 \mathrm{~cm})$ eluting with $1 \mathrm{~L}$ of 3:1:1 hexanes-toluene- $\mathrm{MeOH},{ }^{46}$ followed by $1 \mathrm{~L}$ of $100 \% \mathrm{MeOH}$ at a flow rate of $0.3-0.5$ $\mathrm{mL} / \mathrm{min}$ with $\sim 8 \mathrm{~mL}$ per fraction. The glass column was equipped with a male luer tip for connection to a 100 tube, drop-counting fraction collector. Materials of similar composition as determined by TLC were pooled to give 35 fractions. Compounds 1-10 were all isolated upon elaboration of subfractions of these 35 Sephadex LH-20 column fractions.

The resulting Sephadex LH-20 fractions 24-29 were combined $(183 \mathrm{mg})$ and further purified over silica gel $(5 \times 4.5 \mathrm{~cm})$ using a linear gradient (see General Experimental Procedures) of EtOAc (0-50\%) in hexanes. Subfractions eluting with 40-50\% EtOAc (122 $\mathrm{mg}$ ) were then chromatographed over silica gel $(2.5 \times 5.5 \mathrm{~cm})$ using a linear gradient of $\mathrm{MeOH}(0-5 \%)$ in $\mathrm{CH}_{2} \mathrm{Cl}_{2}$. A later fraction that eluted with $\sim 5 \% \mathrm{MeOH}$ from this column yielded pure (-)-euchrenone-a7 $(\mathbf{5} ; 8 \mathrm{mg})$. Earlier fractions eluting with $\sim 3-4 \% \mathrm{MeOH}$ were combined $(18 \mathrm{mg})$ and further purified over silica gel $(1.5 \times 7 \mathrm{~cm})$ using a step gradient of $\mathrm{MeOH}(0-6 \%)$ in $\mathrm{CH}_{2} \mathrm{Cl}_{2}$ to yield a nearly pure material $(10 \mathrm{mg})$ in fractions eluting with $2.5 \% \mathrm{MeOH}$. Final purification of this material was accomplished by trituration of the dry solid with $1 \mathrm{~mL}$ of $\mathrm{CH}_{2} \mathrm{Cl}_{2}$, followed by addition of five drops of acetone, leaving a pure, insoluble material at the bottom of the vial. Three successive iterations of this procedure, removing and evaporating the soluble portions each time, resulted in a total of $7.2 \mathrm{mg}$ of the new compound 1, (2S)-8-(3-methylbut-2-en-1-yl)-6,7,4' ${ }^{\prime}$-trihydroxyflavanone.

Sephadex LH-20 fraction $16(59 \mathrm{mg})$ was further purified using three successive stages of linear gradient chromatography over silica gel [MeOH (3-10\%) in $\mathrm{CH}_{2} \mathrm{Cl}_{2}(2.5 \times 22 \mathrm{~cm})$, EtOAc $(0-30 \%)$ in hexanes $(2.5 \times 8 \mathrm{~cm})$, and EtOAc $(7-20 \%)$ in hexanes $(1.5 \times 7 \mathrm{~cm})]$, resulting in a semipure solid $(13 \mathrm{mg})$. Final purification of this material was accomplished using a step gradient over silica gel $(1.5 \times 7 \mathrm{~cm})$ with $\mathrm{MeOH}(0-5 \%)$ in $\mathrm{CH}_{2} \mathrm{Cl}_{2}$, to afford (+)-medicarpin $(2 ; 10 \mathrm{mg})$.

Fraction 20 from the Sephadex LH-20 column was purified by linear gradient over silica gel $(2.5 \times 12 \mathrm{~cm})$ with $\mathrm{MeOH}(0-10 \%)$ in $\mathrm{CH}_{2} \mathrm{Cl}_{2}$, resulting in two sets of materials of interest. The first set of fractions eluted with $\sim 1 \% \mathrm{MeOH}(33 \mathrm{mg})$ and were further purified by a linear gradient over silica gel $(2.5 \times 10 \mathrm{~cm})$ with EtOAc $(0-50 \%)$ in hexanes to afford $(+)$ - 
maackiain $(3 ; 12 \mathrm{mg})$. The second set of fractions eluted with $\sim 3 \% \mathrm{MeOH}(24 \mathrm{mg})$ and were further purified by step gradient $(1.5 \times 3.5 \mathrm{~cm})$ with $\mathrm{MeOH}(0-10 \%)$ in $\mathrm{CH}_{2} \mathrm{Cl}_{2}$, followed by a linear gradient column $(1.5 \times 6 \mathrm{~cm})$ with EtOAc $(0-30 \%)$ in hexanes and a final stepgradient cleanup over silica gel $(1.5 \times 8 \mathrm{~cm})$ with EtOAc $(0-50 \%)$ in hexanes, to yield (-)malheuran A (4; $3 \mathrm{mg})$.

Sephadex LH-20 fraction $31(80 \mathrm{mg})$ was purified using a linear gradient with EtOAc (25$45 \%)$ in hexanes over silica gel $(2.5 \times 10 \mathrm{~cm})$. Fractions eluting with $38 \%$ EtOAc were pooled to afford (-)-leachianone G $(6 ; 24 \mathrm{mg})$. Sephadex LH-20 fraction $19(56 \mathrm{mg})$ was purified using a linear gradient with EtOAc $(27-43 \%)$ in hexanes over silica gel $(2.5 \times 10$ $\mathrm{cm})$. Subfractions eluting with $\sim 36 \%$ EtOAc were pooled to afford (-)-malheuran B (7; 10 $\mathrm{mg})$. Combined Sephadex LH-20 fractions 21-23 (28 mg) were purified with a linear gradient of EtOAc $(18-40 \%)$ in hexanes over silica gel $(2.5 \times 6 \mathrm{~cm})$. Fractions eluting with $\sim 30 \%$ EtOAc $(8 \mathrm{mg})$ were further purified by step-gradient chromatography with EtOAc (0$100 \%)$ in hexanes using a Pasteur pipet packed with silica gel $(5 \mathrm{~mm} \times 3 \mathrm{~cm})$ to yield (2S)-5' -(2-methylbut-3-en-2-yl)-8-(3-methylbut-2-en-1-yl)-5,7,2' $4^{\prime}$-tetrahydroxyflavanone (8; $3.2 \mathrm{mg})$.

Fraction 3 from the Sephadex LH-20 column ( $343 \mathrm{mg}$ ) was further purified by VLC over silica gel $(4.5 \times 6 \mathrm{~cm})$ using a step gradient of $\mathrm{MeOH}(0,0.25,0.5,1,2,3,4,5 \%)$ in $\mathrm{CH}_{2} \mathrm{Cl}_{2}$. Fractions 5 and 6 from this column were combined and purified over silica gel (2.5 $\times 11 \mathrm{~cm})$ using a linear gradient of $\mathrm{MeOH}(0-4 \%)$ in $\mathrm{CH}_{2} \mathrm{Cl}_{2}$. A fraction eluting with approximately $2 \% \mathrm{MeOH}$ afforded (-)-deguelin $(\mathbf{9} ; 12 \mathrm{mg})$. Fraction 5 from the Sephadex LH-20 column $(104 \mathrm{mg})$ was purified over silica gel $(2.2 \times 9 \mathrm{~cm})$ using a step gradient of $\mathrm{MeOH}(0,1,2 \%)$ to yield (-)-tephrosin $(\mathbf{1 0} ; 12 \mathrm{mg})$.

(2S)-8-(3-Methylbut-2-en-1-yl)-6, 7,4'-trihydroxyflavanone (1): orange oil; [a $]^{20}{ }_{\mathrm{D}}-22$ (c 0.2, MeOH); UV (MeOH) $\lambda_{\max }(\log \varepsilon) 201$ (4.51), 220 (sh) (4.43), 241 (sh) (4.24), 285 (4.08), $345(3.83) \mathrm{nm}$; ECD (c 0.0019, MeOH) $\lambda(\theta) ; 201\left(-2.0 \times 10^{5}\right), 218\left(2.5 \times 10^{5}\right), 229$ $\left(-4.5 \times 10^{4}\right), 243\left(1.3 \times 10^{5}\right), 308\left(-1.9 \times 10^{5}\right), 353\left(1.3 \times 10^{5}\right) \mathrm{nm}$; IR (film on KBr) $\nu_{\max }$ 3362 (br OH), 1653, 1597, 1518, 1458, 1364, 1338, 1289, 1225, $1172 \mathrm{~cm}^{-1} ;{ }^{1} \mathrm{H},{ }^{13} \mathrm{C}$, and HMBC NMR data, see Table 1; COSY correlations (acetone- $d_{6}, 400 \mathrm{MHz}$ ) H-2 $\rightarrow \mathrm{H}-3 \mathrm{a}$, $\mathrm{H} 3 \mathrm{~b}, \mathrm{H}-2^{\prime} / 6^{\prime} * ; \mathrm{H}-3 \mathrm{a} \rightarrow \mathrm{H}-2, \mathrm{H}-3 \mathrm{~b} ; \mathrm{H}-3 \mathrm{~b} \rightarrow \mathrm{H}-2, \mathrm{H}-3 \mathrm{a} ; \mathrm{H}-2^{\prime} / 6^{\prime} \rightarrow \mathrm{H}-3^{\prime} / 5^{\prime}, \mathrm{H}-2^{*}$; $\mathrm{H}-3^{\prime} / 5^{\prime} \rightarrow \mathrm{H}-2^{\prime} / 6^{\prime} ; \mathrm{H}-1^{\prime \prime} \rightarrow \mathrm{H}-2^{\prime \prime} ; \mathrm{H}-2^{\prime \prime} \rightarrow \mathrm{H}-1^{\prime \prime}, \mathrm{H}_{3}-3^{\prime \prime}-\mathrm{Me}^{*}, \mathrm{H}_{3}-4^{\prime \prime} * \mathrm{H}_{3}-3^{\prime \prime}-\mathrm{Me} \rightarrow$ $\mathrm{H}-2^{\prime \prime} *, \mathrm{H}_{3}-4^{\prime \prime} * ; \mathrm{H}_{3}-4^{\prime \prime} \rightarrow \mathrm{H}-2^{\prime \prime} *, \mathrm{H}_{3}-3^{\prime \prime}$-Me* (*indicates weaker long-range correlation); HRESIMS $m / z 339.1232[\mathrm{M}-\mathrm{H}]^{-}$(calcd for $\mathrm{C}_{20} \mathrm{H}_{19} \mathrm{O}_{5}{ }^{-}, 339.1232$ ).

(+)-Medicarpin (2): yellow oil; [a $]^{20}{ }_{\mathrm{D}}+160\left(\right.$ c 0.2, $\left.\mathrm{CHCl}_{3}\right)$; UV (MeOH) $\lambda_{\max }(\log \varepsilon) 208$ (4.75), 227 (sh) (4.27), 281 (sh) (3.99), 287 (4.03) nm; IR (film on KBr) $v_{\max } 3397$ (br OH), $2929,1621,1599,1496,1473,1447,1345,1277,1210,1155,1114 \mathrm{~cm}^{-1} ;{ }^{1} \mathrm{H}$ NMR data (acetone- $\left.d_{6}, 400 \mathrm{MHz}\right) \delta 7.32(1 \mathrm{H}, \mathrm{d}, J=8.4 \mathrm{~Hz}, \mathrm{H}-1), 7.23(1 \mathrm{H}, \mathrm{d}, J=8.2 \mathrm{~Hz}, \mathrm{H}-7), 6.56$ $(1 \mathrm{H}, \mathrm{dd}, J=8.4,2.4 \mathrm{~Hz}, \mathrm{H}-2), 6.45(1 \mathrm{H}, \mathrm{dd}, J=8.2,2.2 \mathrm{~Hz}, \mathrm{H}-8), 6.38(1 \mathrm{H}, \mathrm{d}, J=2.2 \mathrm{~Hz}$, $\mathrm{H}-10), 6.36(1 \mathrm{H}, \mathrm{d}, J=2.4 \mathrm{~Hz}, \mathrm{H}-4), 5.51(1 \mathrm{H}, \mathrm{d}, J=5.7 \mathrm{~Hz}, \mathrm{H}-11 \mathrm{a}), 4.26(1 \mathrm{H}, \mathrm{dd}, J=10.4$, $5.7 \mathrm{~Hz}, \mathrm{H}-6 \mathrm{a}), 3.75\left(3 \mathrm{H}, \mathrm{s}, \mathrm{OCH} \mathrm{H}_{3}\right), 3.59(1 \mathrm{H}, \mathrm{m}, \mathrm{H}-6 \mathrm{a}), 3.59(1 \mathrm{H}, \mathrm{m}, \mathrm{H}-6 \beta) ;{ }^{13} \mathrm{C}$ NMR data (acetone- $\left.d_{6}, 100 \mathrm{MHz}\right) \delta 162.2(\mathrm{C}, \mathrm{C}-9), 161.9(\mathrm{C}, \mathrm{C}-10 \mathrm{a}), 159.8$ (C, C-3), 157.8 (C, C-4a), 133.2 (CH, C-1), 125.6 (CH, C-7), 120.6 (C, C-6b), 112.9 (C, C-11b), 110.6 (CH, C-2), 
107.0 (CH, C-8), 104.0 (CH, C-4), 97.3 (CH, C-10), 79.5 (CH, C-11a), $67.2\left(\mathrm{CH}_{2}, \mathrm{C}-6\right)$, $55.8\left(\mathrm{CH}_{3}, \mathrm{OCH}_{3}\right), 40.5(\mathrm{CH}, \mathrm{C}-6 \mathrm{a})$; COSY correlations (acetone- $\left.d_{6}, 400 \mathrm{MHz}\right) \mathrm{H}-1 \rightarrow$ $\mathrm{H}-2, \mathrm{H}-11 \mathrm{a}^{*} ; \mathrm{H}-2 \rightarrow \mathrm{H}-1, \mathrm{H}-4 ; \mathrm{H}-4 \rightarrow \mathrm{H}-2 ; \mathrm{H}-7 \rightarrow \mathrm{H}-8 ; \mathrm{H}-6 \mathrm{a} \rightarrow \mathrm{H}-6 \beta, \mathrm{H}-11 \mathrm{a}^{*} ; \mathrm{H}-6 \beta$ $\rightarrow$ H-6a, H-11a*; H-6a $\rightarrow$ H-6a, H-6 $\beta$, H-11a; H-8 $\rightarrow$ H-7, H-10; H-10 $\rightarrow$ H-8; H-11a $\rightarrow \mathrm{H}-6 \mathrm{a}^{*}, \mathrm{H}-6 \beta^{*}, \mathrm{H}-6 \mathrm{a}$ (*indicates weaker long-range correlation); HMBC correlations (acetone- $d_{6}$ ) H-1 $\rightarrow$ C-2, 3, 4*, 4a, 11a; H-6a $\rightarrow$ C-4a, 6a, 6b, 10a*, 11a; H-6 $\rightarrow$ C-6a, 6b, 11a; H-6a $\rightarrow$ C-6, 6b, 7, 10a, 11a, 11b; H-7 $\rightarrow$ C-6a, 8, 9, 10*, 10a; H-8 $\rightarrow$ C-6b, 9, $10 ; \mathrm{OCH}_{3}-9 \rightarrow \mathrm{C}-9 ; \mathrm{H}-10 \rightarrow \mathrm{C}-6 \mathrm{~b}, 8,9,10 \mathrm{a} ; \mathrm{H}-11 \mathrm{a} \rightarrow \mathrm{C}-1,4 \mathrm{a}, 6,6 \mathrm{a}, 6 \mathrm{~b}, 10 \mathrm{a}^{*}, 11 \mathrm{~b}$ (*indicates weak four-bond correlation); HRESIMS m/z 269.0801 [M - H] $]^{-}$(calcd for $\mathrm{C}_{16} \mathrm{H}_{13} \mathrm{O}_{4}^{-}$, 269.0814).

(+)-Maackiain (3): pale yellow, microcrystalline solid; $\mathrm{mp}>140{ }^{\circ} \mathrm{C}(\mathrm{dec}) ;[\mathrm{a}]{ }^{20} \mathrm{D}+102(c$ 0.2, $\mathrm{CHCl}_{3}$ ); UV (MeOH) $\lambda_{\max }(\log \varepsilon) 207$ (4.72), 231 (sh) (4.07), 281 (sh) (3.71), 287 (3.77), 310 (3.98) nm; IR (film on KBr) $v_{\max } 3383$ (br OH), 2918, 1622, 1499, 1473, 1456, $1312,1284,1150,1128,1025,931 \mathrm{~cm}^{-1} ;{ }^{1} \mathrm{H}$ and ${ }^{13} \mathrm{C}$ NMR data (acetone- $d_{6}, 400 \mathrm{MHz}$ ) were consistent with published values ${ }^{35}$ and further supported by HSQC, HMBC, and COSY NMR data (Figures S12-S16, Supporting Information); HRESIMS m/z 283.0597 [M $-\mathrm{H}]^{-}$(calcd for $\mathrm{C}_{16} \mathrm{H}_{11} \mathrm{O}_{5}^{-}, 283.0606$ ).

(-)-Malheuran A (4): off-white, amorphous solid; [a] ${ }^{20}{ }_{\mathrm{D}}-76(c 0.2, \mathrm{MeOH})\left(\right.$ lit. $[\mathrm{a}]^{20} \mathrm{D}$ $-76) ;{ }^{28} \mathrm{IR},{ }^{1} \mathrm{H}$ and ${ }^{13} \mathrm{C}$ NMR spectroscopic data (acetone- $d_{6}, 400 \mathrm{MHz}$; Figures $\mathrm{S} 17$ and S18, Supporting Information), and direct TLC comparison revealed 4 to be identical to an authentic sample, ${ }^{28}$ HRESIMS $\mathrm{m} / \mathrm{z} 407.1854[\mathrm{M}-\mathrm{H}]^{-}$(calcd for $\mathrm{C}_{25} \mathrm{H}_{27} \mathrm{O}_{5}{ }^{-}, 407.1858$ ).

(-)-Euchrenone-a7 (5): orange oil; [a] ${ }^{20}{ }_{\mathrm{D}}-73(c 0.2, \mathrm{MeOH})\left(\mathrm{lit} .[\mathrm{a}]{ }^{20}{ }_{\mathrm{D}}-25\right) ;{ }^{34} \mathrm{UV}$ (MeOH) $\lambda_{\max }(\log \varepsilon) 203$ (4.63), 219 (4.47), 235 (sh) (4.27), 286 (4.19), 316 (sh) (3.79) nm; IR (film on KBr) $v_{\max } 3355$ (br OH), 2923, 1648, 1587, 1517, 1441, 1337, 1286, 1210 , $1168,1113,1044,974 \mathrm{~cm}^{-1} ;{ }^{1} \mathrm{H}$ and ${ }^{13} \mathrm{C}$ NMR data (acetone- $d_{6}, 400 \mathrm{MHz}$ ) were consistent with published values ${ }^{33,43}$ and further supported by HSQC, HMBC, and COSY NMR data (Figures S19-S23, Supporting Information); HRESIMS m/z 339.1231 [M- H $]^{-}$(calcd for $\left.\mathrm{C}_{20} \mathrm{H}_{19} \mathrm{O}_{5}{ }^{-}, 339.1232\right)$.

(2S)-Leachianone $G$ (6): orange oil; [a $]^{20}{ }_{\mathrm{D}}-58(c 0.2, \mathrm{MeOH})\left(\right.$ lit. $\left.[\mathrm{a}]{ }^{20} \mathrm{D}-17\right) ;{ }^{37} \mathrm{UV}$ $(\mathrm{MeOH}) \lambda_{\max }(\log \varepsilon) 204$ (4.67), 227 (sh) (4.37), 292 (4.22), 338 (3.60) nm; IR (film on $\mathrm{KBr}) v_{\max } 3372$ (br OH), 2925, 1636, 1605, 1518, 1437, 1384, 1300, 1231, 1171, 1103, $1074 \mathrm{~cm}^{-1} ;{ }^{1} \mathrm{H}$ and ${ }^{13} \mathrm{C}$ NMR data (acetone- $d_{6}, 400 \mathrm{MHz}$ ) were consistent with published values $^{39,40}$ and further supported by HSQC, HMBC, and COSY NMR data (Figures S24S28, Supporting Information); HRESIMS $m / z 355.1183[\mathrm{M}-\mathrm{H}]^{-}$(calcd for $\mathrm{C}_{20} \mathrm{H}_{20} \mathrm{O}_{6}{ }^{-}$, 355.1182).

(-)-Malheuran B (7): yellow, amorphous solid; [a] ${ }^{20}{ }_{\mathrm{D}}-67(c$ c $0.2, \mathrm{MeOH})\left(\mathrm{lit} .[\mathrm{a}]^{20} \mathrm{D}\right.$ $-90) ;{ }^{28} \mathrm{IR},{ }^{1} \mathrm{H}$ and ${ }^{13} \mathrm{C}$ NMR spectroscopic data (acetone- $d_{6}, 400 \mathrm{MHz}$; Figures S29 and S30, Supporting Information), and direct TLC comparison revealed 7 to be identical to an authentic sample, ${ }^{28}$ HRESIMS $\mathrm{m} / \mathrm{z} 407.1863[\mathrm{M}-\mathrm{H}]^{-}$(calcd for $\mathrm{C}_{25} \mathrm{H}_{27} \mathrm{O}_{5}{ }^{-}$407.1858).

(2S)-5'-(2-Methylbut-3-en-2-yl)-8-(3-methylbut-2-en-1-yl)-5, 7,2',4'-tetrahydoxyflavanone (8): yellow, amorphous solid; [a $]^{20} \mathrm{D}-69(c 0.2, \mathrm{MeOH})\left(\mathrm{lit} .[\mathrm{a}]{ }^{20} \mathrm{D}-50\right) ;{ }^{28} \mathrm{IR},{ }^{1} \mathrm{H}$ and ${ }^{13} \mathrm{C}$ 
NMR spectroscopic data (acetone- $d_{6}, 400 \mathrm{MHz}$; Figures S31 and S32, Supporting

Information), and direct TLC comparison revealed $\mathbf{8}$ to be identical to an authentic sample; 31 HRESIMS $m / z 423.1803[\mathrm{M}-\mathrm{H}]^{-}$(calcd for $\mathrm{C}_{25} \mathrm{H}_{27} \mathrm{O}_{5}{ }^{-}, 423.1808$ ).

(-)-Deguelin (9): yellow, amorphous solid; [a $]^{20}{ }_{\mathrm{D}}-45\left(c 0.2, \mathrm{CHCl}_{3}\right)\left(\right.$ lit. $\left.[\mathrm{a}]^{20} \mathrm{D}-107\right) ;{ }^{41}$

UV (MeOH) $\lambda_{\max }(\log \varepsilon) 203$ (4.68), 237 (4.43), 251 (4.43), 270 (4.51) 297 (4.08), 317

(4.03) nm; IR (film on KBr) $v_{\max } 2950,1672,1636,1597,1577,1513,1442,1345,1274$,

$1214,1199,1112,1095 \mathrm{~cm}^{-1} ;{ }^{1} \mathrm{H}$ and ${ }^{13} \mathrm{C}$ NMR data (acetone- $d_{6}, 400 \mathrm{MHz}$ ) were

consistent with published values ${ }^{41}$ and further supported by HSQC, HMBC, and COSY

NMR data (Figures S33-S37, Supporting Information); HRESIMS m/z $393.1353[\mathrm{M}-\mathrm{H}]^{-}$ (calcd for $\mathrm{C}_{23} \mathrm{H}_{21} \mathrm{O}_{6}{ }^{-}, 393.1338$ ).

(-)-Tephrosin (10): yellow, microcrystalline solid; mp 89-106 ${ }^{\circ} \mathrm{C}$; $[\mathrm{a}]^{20} \mathrm{D}-86(c 0.2$, $\mathrm{CHCl}_{3}$ ) (lit. $\left.\left.[\mathrm{a}]\right]^{20} \mathrm{D}-100\right) ;{ }^{28} \mathrm{IR},{ }^{1} \mathrm{H}$ and ${ }^{13} \mathrm{C}$ NMR spectroscopic data (acetone- $d_{6}, 400$ MHz; Figures S38 and S39, Supporting Information), and direct TLC comparison revealed 10 to be identical to an authentic sample; ${ }^{28}$ HRESIMS $\mathrm{m} / \mathrm{z} 409.1292[\mathrm{M}-\mathrm{H}]^{-}$(calcd for $\left.\mathrm{C}_{23} \mathrm{H}_{21} \mathrm{O}_{7}^{-}, 409.1287\right)$.

\section{Anthelmintic and Toxicity Assays}

The $A$. ceylanicum life cycle was maintained by passage through Syrian hamsters (Mesocricetus auratus) as described. ${ }^{9}$ Animals were housed in the Central Washington University (CWU), and all experiments involving hamsters were approved by the CWU Institutional Animal Care and Use Committee (Protocol Number A081401). For each round of the ex vivo assay, 8-10 hamsters were orally infected with 150 L3 (infectious stage) hookworm larvae. On day 21 PI, the fecal material was gathered, the hamsters sacrificed, and the small intestine collected. The fecal material contains hookworm eggs and was used for the production of more infectious larvae for subsequent experiments. Adult worms were harvested from the intestine using tweezers and a dissecting microscope. The worms were placed in phosphate buffer saline (PBS) with penicillin/streptomycin (pen/strep) and fungizone, an antifungal agent. Following harvest into a Petri dish, the worms were washed three times in RPMI medium containing fungizone $(25 \mu \mathrm{g} / \mathrm{mL})$ and $20 \times$ pen/strep, and 15 $\mathrm{mL}$ of fresh RPMI medium was added in successive (15 min each) washes. Worms were placed in an incubator overnight $\left(37^{\circ} \mathrm{C} ; 5 \% \mathrm{CO}_{2}\right)$, in a solution of RPMI medium supplemented with fungizone $(25 \mu \mathrm{g} / \mathrm{mL})$ and $20 \times$ pen/strep and $50 \%$ fetal bovine serum (FBS) as a protein source. After a $24 \mathrm{~h}$ incubation, the most active worms were placed in a 24-well tissue culture plate. To ensure randomization, one worm was placed in each well before going back to a well already containing worms. Wells typically contained 10 worms. In addition to test wells (in triplicate), there were negative control wells with $1 \%$ DMSO. Plant materials dissolved in $100 \%$ DMSO were diluted to chosen concentrations in the RPMI, fungizone $(25 \mu \mathrm{g} / \mathrm{mL}), 20 \times$ pen/strept medium, and 50\% FBS medium to reach a final concentration of $1 \%$ DMSO. Plates were checked daily for 5 days to determine the percent survival and motility of the worms. Dead and living worms were counted to calculate percent survival. The motility scale of 0 to 3 , where 3 is for fully active worms with sinusoidal and whip-like motion, assesses the movement of the worm under the light 
and heat of the dissecting microscope and gentle manipulation by the researcher. Healthy worms rapidly whip their entire bodies back and forth to move through solution.

Toxicity tests were conducted using spleen cells, or splenocytes, to assess the potential biological activity of plant compounds on healthy mammalian cells by measuring cell cloning efficiency (proliferation). ${ }^{47,48}$ Splenocytes were collected as previously described. ${ }^{9}$ Briefly, hamsters were sacrificed and the spleens harvested. Single-cell preparations were made using $70 \mu \mathrm{M}$ cell strainers (Corning, Durham, NC, USA). Splenocytes were depleted of red blood cells by lysis and washed with RPMI medium. The spleen cells were plated in triplicate $\left(10^{5}\right.$ per well) in 96 -well plates with different test doses of each compound. In positive control wells, cells were incubated with concanavalin A, a known stimulus of splenocytes, mainly T lymphocytes, ${ }^{9}$ while negative control wells contained $1 \%$ DMSO only. The proliferation of cells was estimated by 5-bromo- $2^{\prime}$-deoxyuridine incorporation using a colorimetric kit (Roche Diagnostics, Penzberg, Germany). ${ }^{9,10}$ The stimulation index indicative of cloning efficiency was calculated as the ratio of mean optical density at $450 \mathrm{~nm}$ of plant extract wells to negative control wells (tissue culture medium and 1\% DMSO only). ${ }^{9,10}$ It is assumed that a ratio of 1 will be obtained in the absence of negative effects of the experimental compound(s) on healthy mammalian cells.

\section{Supplementary Material}

Refer to Web version on PubMed Central for supplementary material.

\section{Acknowledgments}

The authors are grateful to the National Institutes of Health, National Center for Complementary and Integrative Health, for funding under award R15AT008546. ECD spectra were acquired by the Protein Science Translation Core, part of the South Carolina Lipidomics and Pathology Center of Biomedical Research Excellence, National Institutes of Health Grant MUCR-2211000-89623-2021-02. The authors are grateful to Prof. M. Cappello and Ms. L. Harrison, Yale School of Medicine, New Haven, CT, for providing the hookworm larvae and their thoughtful suggestions during the course of this work. We would like to thank Mr. J. Betz, Ms. M. Bottcher, Ms. S. Unni, Ms. A. Shindruk, Ms. S. Landreth, Ms. A. Berndt, Ms. M. Denoso, Ms. K. McClellan, and Ms. D. Ek for technical assistance.

\section{REFERENCES}

1. De Silva NR, Brooker S, Hotez PJ, Montresor A, Engels D, Savioli L. Trends Parasitol. 2003; 19:547-551. [PubMed: 14642761]

2. Hotez PJ, Brooker S, Bethony JM, Bottazzi ME, Loukas A, Xiao S. N. Engl. J. Med. 2004; 351:799-807. [PubMed: 15317893]

3. Brooker S, Hotez PJ, Bundy DA. PLoS Neglected Trop. Dis. 2010; 4:e779.

4. Bungiro R, Cappello M. Curr. Infect. Dis. Rep. 2011; 13:210-207. [PubMed: 21462001]

5. Hsu YC, Lin JT. N. Engl. J. Med. 2012; 366:e20. [PubMed: 22455438]

6. Ngui R, Lim YAL, Traub R, Mahmud R, Mistam MS. PLoS Neglected Trop. Dis. 2012; 6:e1522.

7. Bethony J, Brooker S, Albonico M, Geiger SM, Loukas A, Diemert D, Hotez PJ. Lancet. 2006; 367:1521-1532. [PubMed: 16679166]

8. Cappello M, Hawdon JM, Jones BF, Kennedy WP, Hotez PJ. Mol. Biochem. Parasitol. 1996; 80:113-117. [PubMed: 8885227]

9. Dondji B, Bungiro RD, Harrison LM, Vermeire JJ, Bifulco C, McMahon-Pratt D, Cappello M. Infect. Immun. 2008; 76:2560-2567. [PubMed: 18347036] 
10. Dondji B, Sun T, Bungiro RD, Vermeire JJ, Harrison LM, Bifulco C, Cappello M. Parasite Immunol. 2010; 32:406-413. [PubMed: 20500671]

11. Chadderdon RC, Cappello M. J. Infect. Dis. 1999; 179:1235-1241. [PubMed: 10191228]

12. Del Valle A, Jones BF, Harrison LM, Chadderdon RC, Cappello M. Mol. Biochem. Parasitol. 2003; 129:167-177. [PubMed: 12850261]

13. Stassens P, Bergum PW, Gansemans Y, Jespers L, Laroche Y, Huang S, Maki S, Messens J, Lauwereys M, Capello M, Hotez PJ, Lasters I, Vlasuk GP. Proc. Natl. Acad. Sci. U. S. A. 1996; 93:2149-2154. [PubMed: 8700900]

14. Chu D, Bungiro RD, Ibanez M, Harrison LM, Campodonico E, Jones BF, Mieszczanek J, Kuzmic P, Capello M. Infect. Immun. 2004; 72:2214-2221. [PubMed: 15039345]

15. Crompton DW, Nesheim MC. Annu. Rev. Nutr. 2002; 22:35-59. [PubMed: 12055337]

16. Borkow G, Teicher C, Bentwich Z. PLoS Neglected Trop. Dis. 2007; 1:e160.

17. Cooper PJ, Chico M, Sandoval C, Espinel I, Guevara A, Levine MM, Griffin GE, Nutman TB. Infect. Immun. 2001; 69:1574-1580. [PubMed: 11179329]

18. Nielsen NO, Simonsen PE, Magnussen P, Magesa S, Friis H. Trans. R. Soc. Trop. Med. Hyg. 2006; 100:543-550. [PubMed: 16324731]

19. O’Neal SE, Guimaraes LH, Machado PR, Alcantara L, Morgan DJ, Passos S, Glesby MJ, Carvalho EM. J. Infect. Dis. 2007; 195:142-148. [PubMed: 17152018]

20. Walson JL, John-Stewart G. PLoS Neglected Trop. Dis. 2007; 1:e102.

21. World Bank. School Deworming. Washington, DC: World Bank; 2003. https:// openknowledge.worldbank.org/handle/10986/9722 [accessed on July 17, 2016]

22. World Health Assembly, 54. 2001. World Health Organization; Schistosomiasis and SoilTransmitted Helminth Infections. http://www.who.int/iris/handle/ 10665/78794\#sthash.qHlvWrgq.dpuf [accessed on July 17, 2016]

23. Albonico M, Engels D, Savioli L. Int. J. Parasitol. 2004; 34:1205-1210. [PubMed: 15491582]

24. Humphries D, Mosites E, Otchere J, Twum WA, Woo L, Jones-Sanpei H, Harrison LM, Bungiro RD, Benham-Pyle B, Bimi L, Edoh D, Bosompem K, Wilson M, Cappello M. Am. J. Trop. Med. Hyg. 2011; 84:792-800. [PubMed: 21540391]

25. Humphries D, Simms BT, Davey D, Otchere J, Quagraine J, Terryah S, Newton S, Berg E, Harrison LM, Boakye D, Wilson M, Cappello M. Am. J. Trop. Med. Hyg. 2013; 89:540-548. [PubMed: 23836564]

26. Toyang NJ, Ateh EN, Keiser J, Vargas M, Bach H, Tane P, Sondengam LB, Davis H, Bryant J, Verpoorte R. J. Ethnopharmacol. 2012; 44:700-704.

27. Kone WM, Vargas M, Keiser J. Parasitol. Res. 2012; 110:2351-2362. [PubMed: 22200959]

28. Treger RS, Otchere J, Keil MF, Quagraine JE, Rai G, Mott BT, Humphries DL, Wilson M, Cappello M, Vermeire JJ. Am. J. Trop. Med. Hyg. 2014; 90:71-74. [PubMed: 24297811]

29. Cane JH, Weber M, Miller S. West. N. Am. Naturalist. 2012; 72:16-20.

30. McMahon, MM., Isely, D. Jepson eFlora. Jepson Flora Project; Dalea ornata and Dalea searlsiae. http://ucjeps.berkeley.edu/cgi-bin/get_IJM.pl?tid=22274 and http://ucjeps.berkeley.edu/cgi-bin/ get_IJM.pl?tid=22288 [both accessed on January 7, 2016]

31. Belofsky G, Aronica M, Foss E, Diamond J, Santana F, Darley J, Dowd PF, Coleman CM, Ferreira D. J. Nat. Prod. 2014; 77:1140-1149. [PubMed: 24761805]

32. Slade D, Ferreira D, Marais JPJ. Phytochemistry. 2005; 66:2177-2215. [PubMed: 16153414]

33. Gupta DR, Ahmed B. J. Nat. Prod. 1984; 47:958-963. [PubMed: 6549468]

34. Herath HMTB, Dassanayake RS, Priyadarshani AMA, de Silva S, Wannigama GP, Jamie J. Phytochemistry. 1998; 47:117-119.

35. Chaudhuri SK, Huang L, Fullas F, Brown DM, Wani MC, Wall ME, Tucker JC, Beecher CWW, Kinghorn AD. J. Nat. Prod. 1995; 58:1966-1969. [PubMed: 8691215]

36. Mizuno M, Tanaka T, Matsuura N, Iinuma M, Cheih C. Phytochemistry. 1990; 29:2738-2740.

37. Han AR, Kang YJ, Widono T, Lee SK, Seo EK. J. Nat. Prod. 2006; 69:719-721. [PubMed: 16643064] 
38. Jung HA, Jeong DM, Chung HY, Lim HA, Kim JY, Yoon NY, Choi JS. Biol. Pharm. Bull. 2008; 31:908-915. [PubMed: 18451517]

39. Iinuma M, Ohyama M, Tanaka T, Lang FA. J. Nat. Prod. 1993; 56:2212-2215.

40. Chen R, Liu X, Zou J, Yin Y, Ou B, Li J, Wang R, Xie D, Zhang P, Dai J. Adv. Synth. Catal. 2013; 355:1817-1828.

41. Luyengi L, Lee IS, Mar W, Fong HHS, Pezzuto JM, Kinghorn AD. Phytochemistry. 1994; 36:1523-1526.

42. Gersdorff WA. J. Am. Chem. Soc. 1931; 53:1897-1901.

43. Dewick, PM. Medicinal Natural Products: A Biosynthetic Approach. Chichester, UK: John Wiley \& Sons, Ltd.; 2001. p. 155-157.

44. Dat NT, Lee JH, Lee K, Hong YS, Kim YH, Lee JJ. J. Nat. Prod. 2008; 71:1696-1700. [PubMed: 18841906]

45. Hollingworth, RM. Handbook of Pesticide Technology. 2nd. Krieger, RI., editor. San Diego: Academic Press; 2001. p. 1181-1183.

46. Miller TW, Chaiet L, Cole DJ, Cole LJ, Flor JE, Goegelman RT, Gullo VP, Joshua H, Kempf AJ, Krellwitz WR, Monaghan RL, Ormmond RE, Wilson KE, Albers-Schonberg G, Putter I. Antimicrob. Agents Chemother. 1979; 15:368-371. [PubMed: 464562]

47. Yang Z, Wang Y, Wang Y, Zhang Y. Food Chem. 2012; 131:617-625.

48. Ekwall, B., Silano, V., Paganuzzi-Stammati, A., Zucco, F. Short-Term Toxicity Tests for NonGenotoxic Effects. Bourdeau, P.Somers, E.Richardson, GM., Hickman, JR., editors. Chichester, UK: John Wiley \& Sons Ltd.; 1990. p. 75-97. 


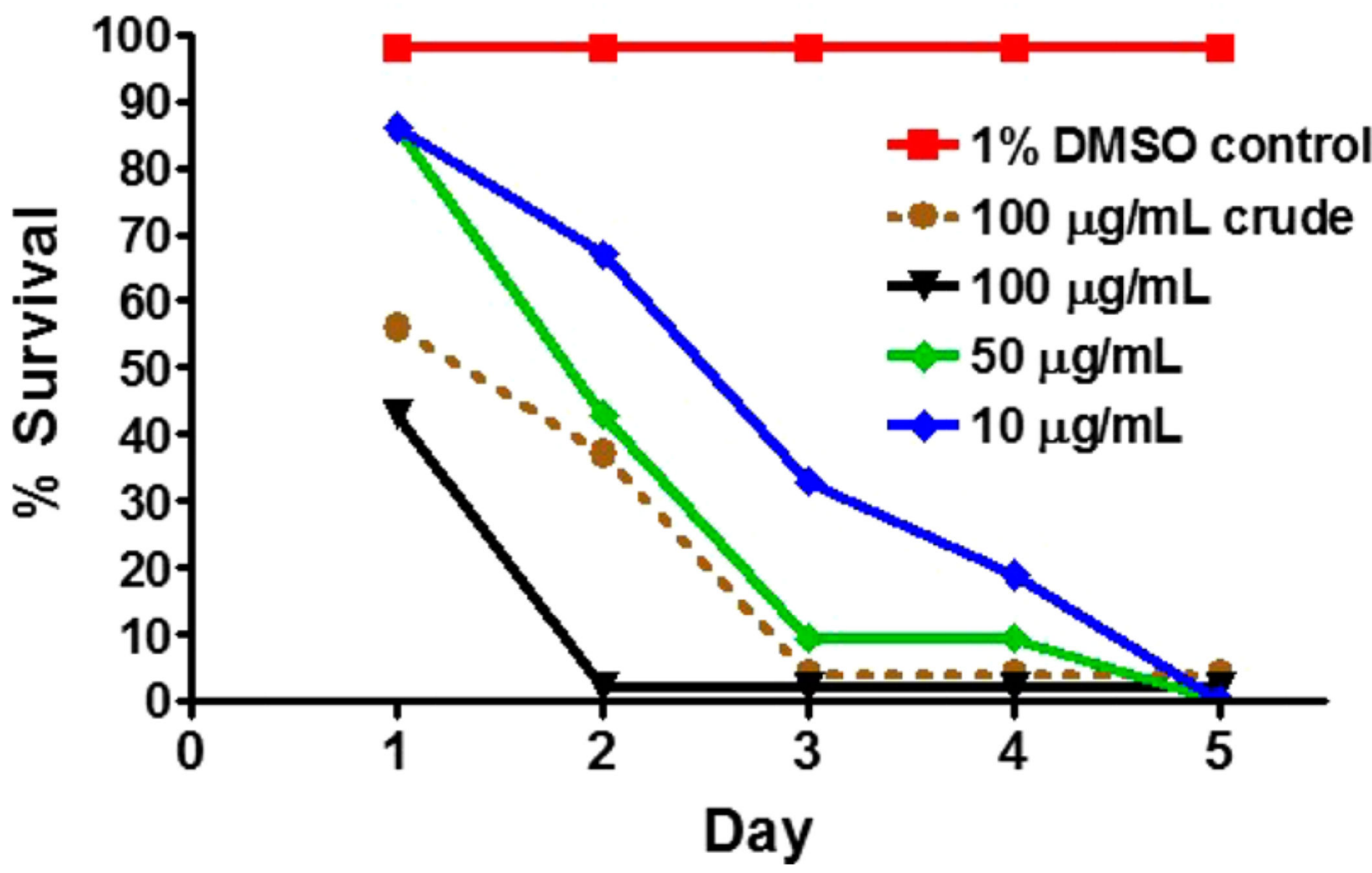

Figure 1.

Dose dependence $(100,50$, and $10 \mu \mathrm{g} / \mathrm{mL})$ of $D$. ornata enriched, pooled fraction from VLC on A. ceylanicum ex vivo survival compared to the crude extract $(100 \mu \mathrm{g} / \mathrm{mL})$ and to $1 \%$ DMSO control. Motility was also strongly affected, starting at day 1 for all concentrations except DMSO control. 


\section{Table 1}

NMR Spectroscopic Data (400 MHz, Acetone- $d_{6}$ ) for Flavanone 1

\begin{tabular}{|c|c|c|c|}
\hline position & $\delta_{\mathrm{C}}$, type & $\delta_{\mathbf{H}}(J$ in $\mathbf{H z})$ & HМBC $^{a}$ \\
\hline 2 & $80.5, \mathrm{CH}$ & $5.38, \mathrm{dd}(13.0,2.8)$ & $4,1^{\prime}, 2^{\prime} / 6^{\prime}$ \\
\hline $3 a$ & $44.9, \mathrm{CH}_{2}$ & 2.96, dd $(16.8,13.0)$ & $2,4,1^{\prime}$ \\
\hline $3 \beta$ & & $2.72, \mathrm{dd}(16.8,2.8)$ & 4,10 \\
\hline 4 & $191.1, \mathrm{C}$ & & \\
\hline 5 & $108.7, \mathrm{CH}$ & $7.18, \mathrm{~s}$ & $6,7,8^{d}, 9,10$ \\
\hline 6 & $140.4, \mathrm{C}$ & & \\
\hline OH-6 & & $8.23,^{c} \mathrm{~s}$ & not observed \\
\hline 7 & 156.3, C & & \\
\hline $\mathrm{OH}-7$ & & $8.49,^{c} \mathrm{~s}$ & not observed \\
\hline 8 & 117.1, C & & \\
\hline 9 & $152.0, \mathrm{C}$ & & \\
\hline 10 & 114.0, C & & \\
\hline $1^{\prime}$ & $131.8,{ }^{b} \mathrm{C}$ & & \\
\hline $2^{\prime} / 6^{\prime}$ & $128.8, \mathrm{CH}$ & $7.40, \mathrm{~d}(8.5)$ & $2,3^{\prime} / 5^{\prime}, 4^{\prime}, 6^{\prime} / 2^{\prime} e$ \\
\hline $3^{\prime} / 5^{\prime}$ & $116.1, \mathrm{CH}$ & $6.89, \mathrm{~d}(8.5)$ & $1^{\prime}, 4^{\prime}, 5^{\prime} / 3^{\prime} e, 2^{\prime} / 6^{\prime}$ \\
\hline $4^{\prime}$ & $158.5, \mathrm{C}$ & & \\
\hline $\mathrm{OH}-4^{\prime}$ & & $8.63,^{c} \mathrm{~s}$ & not observed \\
\hline $1^{\prime \prime}$ & $23.2, \mathrm{CH}_{2}$ & $3.35, \mathrm{~d}(7.1)$ & $7,8,9,2^{\prime \prime}, 3^{\prime \prime}, 4^{\prime \prime} d$ \\
\hline $2^{\prime \prime}$ & $123.2, \mathrm{CH}$ & $5.24, \mathrm{~m}$ & $8,1^{\prime \prime}, 3^{\prime \prime}-\mathrm{Me}, 4^{\prime \prime}$ \\
\hline $3^{\prime \prime}$ & $131.9^{b}, \mathrm{C}$ & & \\
\hline $\mathrm{Me}-3^{\prime \prime}$ & $18.0, \mathrm{CH}_{3}$ & $1.64, \mathrm{~s}$ & $2^{\prime \prime}, 3^{\prime \prime}, 4^{\prime \prime}$ \\
\hline $4^{\prime \prime}$ & $26.0, \mathrm{CH}_{3}$ & $1.62, \mathrm{~s}$ & $2^{\prime \prime}, 3^{\prime \prime}, 3^{\prime \prime}-\mathrm{Me}$ \\
\hline
\end{tabular}

${ }^{a} \mathrm{HMBC}$ correlations, optimized for $8 \mathrm{~Hz}$, are from proton(s) stated to the indicated carbon.

${ }^{b, c}$ Assignments may be interchanged.

$d_{\text {Indicates weak 4-bond correlation. }}$

Indicates correlations to symmetric, equivalent carbons. 


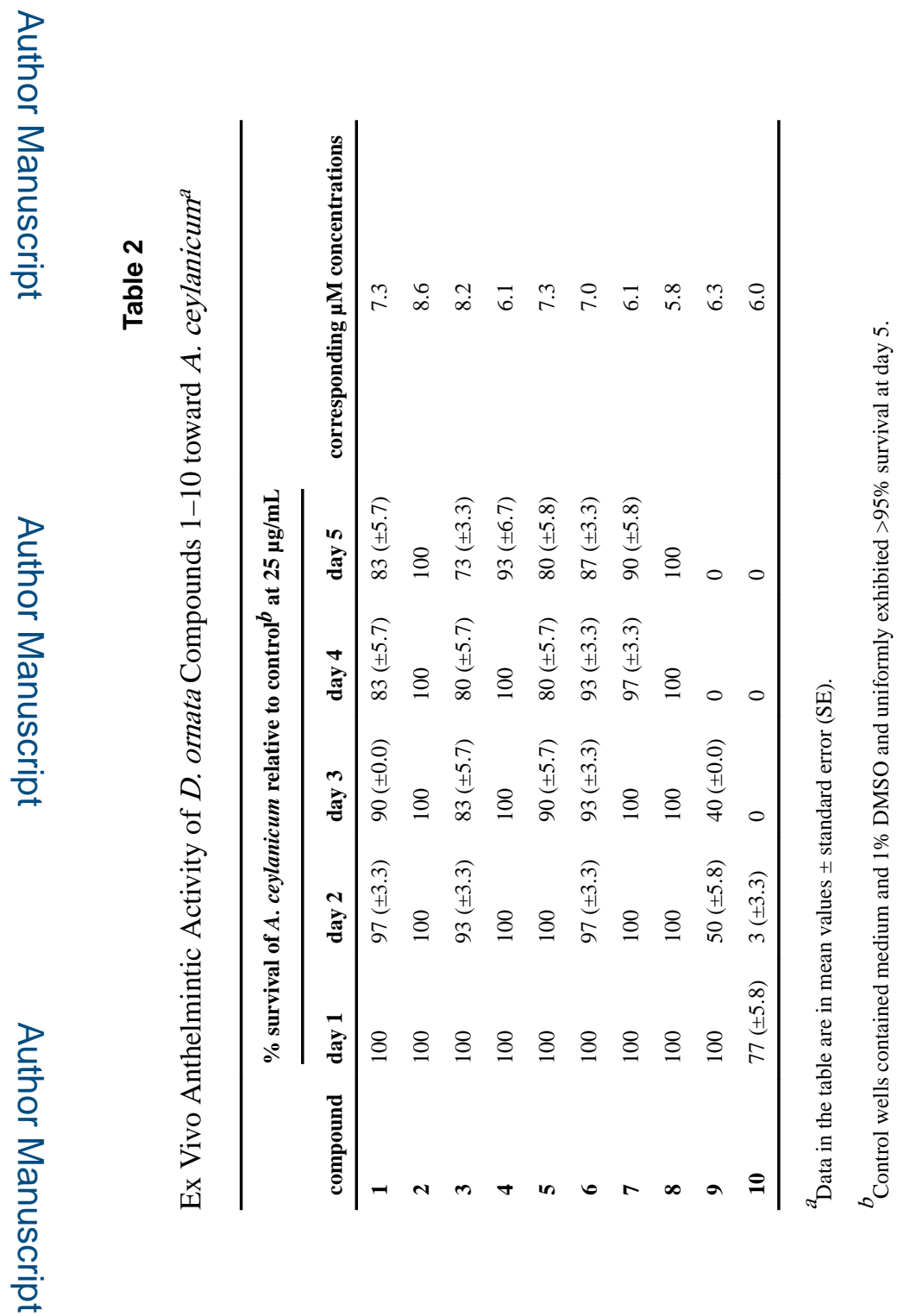

J Nat Prod. Author manuscript; available in PMC 2017 January 24. 